\title{
INTRODUCTION TO SYMPOSIUM ON KOH \& BUCHWALD, “THE CRIME OF AGGRESSION: THE UNITED STATES PERSPECTIVE”
}

\author{
Dapo Akande*
}

In June 2010, the States Parties to the Statute of the International Criminal Court gathered in Kampala, Uganda, at the first conference to review the Statute. One of the main items on the agenda was a proposal to amend the Statute so as to operationalize the jurisdiction of the International Criminal Court ("ICC") over aggression. Article 5(1) of the Statute of the Court adopted in Rome ("Rome Statute" / "ICC Statute") adopted in 1998 had included the crime of aggression as one the four crimes over which the Court has jurisdiction, together with genocide, war crimes and crimes against humanity. However, despite the fact that the Nuremberg and Tokyo Tribunals which were convened at the end of World War II had prosecuted individuals for crimes against peace, states which attended the Rome Conference in 1998 were unable to agree on a definition of aggression or on the conditions under which the ICC should be able to exercise jurisdiction over the crime. For that reason, Article 5(2) of the Rome Statute provided that:

The Court shall exercise jurisdiction over the crime of aggression once a provision is adopted in accordance with articles 121 and 123 defining the crime and setting out the conditions under which the Court shall exercise jurisdiction with respect to this crime. Such a provision shall be consistent with the relevant provisions of the Charter of the United Nations.

The reference to Article 123 was to the Review Conference to be convened seven years after the entry into force of the Statute to consider any amendments. As the Statute entered into force in 2002, a review conference was duly convened but only took place in Kampala in 2010.

Seemingly against all odds, the parties gathered at the Review Conference succeeded in adopting amendments to the ICC Statute with respect to the crime of aggression. ${ }^{1}$ Article 8bis(1) sets out a definition of the "crime of aggression" as the "planning, preparation, initiation or execution, by a person in a position effectively to exercise control over or to direct the political or military action of a State, of an act of aggression which, by its character, gravity and scale, constitutes a manifest violation of the Charter of the United Nations." 2 Articles 15 bis and ter then set out the conditions under which the crime of aggression may be prosecuted by the Court,

* Professor of Public International Law, University of Oxford, Faculty of Law, Yamani Fellow at St. Peter's College and Co-Director of the Oxford Institute for Ethics, Law and Armed Conflict \& the Oxford Martin Programme on Human Rights for Future Generations.

Originally published online 02 March 2016.

${ }^{1}$ For a general discussion of the aggression amendments and the process of their adoption, see Stefan Barriga \& Leena Grover, $\underline{A}$ Historic Breakthrough on the Crime of Aggression, 105 AJIL 517 (2011); Claus Kreß \& Leonie von Holtzendorff, The Kampala Compromise on the Crime of Aggression, 8 J. INT'L CRIM. JUST. 1179 (2010); and the articles in the 10th Anniversary Special Issue of the Journal of International Criminal Justice "Aggression: After Kampala" 10 J. INT'L CRIM. JusT. 1-290 (2012).

2 Art. 8bis(2) defines "act of aggression" as "the use of armed force by a State against the sovereignty, territorial integrity or political independence of another State, or in any other manner inconsistent with the Charter of the United Nations." It also provides that any of a number of acts set out in United Nations General Assembly Resolution 3314 (XXIX) of 14 Dec. 1974 qualify as an act of aggression. 
distinguishing between situations referred to the Court by a State Party or taken up by the Prosecutor propio motu, on the one hand, and situations where there is a Security Council referral, on the other hand. However common to all categories was that the Court may only exercise jurisdiction with respect to the crime of aggression, "subject to a decision to be taken after 1 January 2017 by the same majority of States parties as is required for the adoption of an amendment to the Statute." 3 In addition, the Court may only exercise jurisdiction with respect to crimes of aggression committed one year after the ratification or acceptance of the amendment by thirty States Parties. ${ }^{4}$ In 2010, this may have seemed a long delay before the Court would be able to exercise jurisdiction over the crime. However, in early 2016, we are less than a year away from the moment when the States Parties may take a decision to operationalize the crime. Furthermore, with 26 ratifications or acceptances of the amendments as of February $2015^{5}$ and with more seemingly to follow, ${ }^{6}$ it appears likely that the jurisdiction of the ICC over aggression is not that far off.

This, therefore, is a good time to give serious consideration to the implications that ICC jurisdiction over the crime of aggression will have both with regard to international law but also in international politics. Many questions regarding the crime and the jurisdiction of the Court over it remain unresolved. Some basic questions regarding the material scope of the crime seem no clearer now than they were in 2010. Under the amendments, only acts of aggression, which by character, gravity and scale, constitute a manifest violation of the UN Charter would amount to the crime of aggression. But what exactly amounts to a "manifest violation of the Charter"? Does the definition refer to serious violations of the Charter provisions on the use of force? Obvious violations of those provisions? Or only those serious violations which are obviously illegal? Furthermore, questions remain as to who will be subject to the jurisdiction of the Court with respect to the crime of aggression. Under the Rome Statute, the Court is entitled to exercise jurisdiction over nationals of states not party to the Statute in situations referred to the Court by the Security Council, or where the national of the nonparty commits a crime on the territory of a party to the Statute (or of a state that has made a declaration accepting jurisdiction of the Court)..$^{7}$ Under the aggression amendments, the Court shall not exercise jurisdiction with respect to aggression committed by a national of a nonparty or committed on the territory of a nonparty. ${ }^{8}$ However, it remains unclear whether the Court will be able to exercise jurisdiction over nationals of parties to the Rome Statute who do not ratify or accept the aggression amendments. If the normal jurisdictional provisions contained in Article 12 of the ICC Statute are applicable, the Court will be competent to exercise jurisdiction over all persons who commit aggression on the territory of states who have accepted the aggression amendments, with the exception of nationals of nonparties to the Statute who are specifically excluded from jurisdiction by the aggression amendments. ${ }^{9}$ However, the second sentence of Article 121(5) of the ICC Statute, dealing with amendments to the Statute provides that: "In respect of a State Party which has not accepted the amendment, the Court shall not exercise its jurisdiction regarding a crime covered by the amendment when committed by that State Party's nationals or on its territory." This suggests a different jurisdictional regime relating to crimes

\footnotetext{
${ }^{3}$ Rome Statute of the International Criminal Court arts. 15bis(3) \& 15ter(3), July 17, 1998, 2187 UNTS.

${ }^{4}$ Rome Statute of the International Criminal Court arts. 15bis(2) \& 15ter(2), July 17, 1998, 2187 UNTS.

${ }^{5}$ For updated figures on ratifications/acceptances of the ICC Aggression amendments, see Amendments on the crime of aggression to the Rome Statute of the International Criminal Court, UnITED NATIONS TREATY COLLECTION.

${ }^{6}$ For an overview of actions taken domestically by states with respect to the ratification/acceptance of the amendments see $\underline{\text { Status }}$ of ratification and implementation, THE Global CAMPAign for RATIFICATION AND IMPLEMENTATION OF THE KAMPALA AMENDMENTS ON THE CRIME OF AGGRESSION.

7 See Rome Statute of the International Criminal Court arts. 12(2)(a) \& 12(3), July 17, 1998, 2187 UNTS, and, generally, Dapo Akande, The Jurisdiction of the International Criminal Court over Nationals of Non-Parties: Legal Basis and Limits, 1 J. INT'L CRIM. JUST. 618-650 (2003).

${ }^{8}$ Rome Statute of the International Criminal Court art. 15bis(5), July 17, 1998, 2187 UNTS.

${ }^{9} \underline{I d}$.
} 
introduced by amendments to the Statute. Under that regime, nationals of States Parties are excluded from the jurisdiction of the Court even when they commit a crime on the territory of another party. Which jurisdictional regime will apply to aggression requires clarification as this will have significance for those states party to the ICC Statute who choose not to ratify or accept the aggression amendments. ${ }^{10}$ Likewise questions remain as to whether the Court will be acting in accordance with international law were it to seek to adjudicate on a use of force by a state that has not given its consent to the adjudication by the Court on that question. ${ }^{11}$

In the lead article in the April 2015 issue of the American Journal of International Law, ${ }^{12}$ Harold Koh and Todd Buchwald, both of whom were leaders of the U.S. delegation at the Kampala review Conference, consider these and other issues. They provide a critique of the definition of the crime of aggression provided for in the aggression amendments; examine issues relating to the jurisdiction of the Court and domestic courts over that crime; and consider the role of the Security Council with respect to aggression. One of the main focuses of their piece is a consideration of how best to prevent the new jurisdiction over the crime of aggression from chilling uses of force they consider legitimate, particularly humanitarian intervention that is not authorized by the Security Council. In the July 2015 issue of the Journal, Alain Pellet and Bing Bing Jia respond to Koh and Buchwald. ${ }^{13}$

This AJIL Unbound symposium includes four pieces which provide further consideration of issues relating to the crime of aggression and some responses to the Koh \& Buchwald article. Nicholas Rostow's piece "The International Criminal Court, Aggression, and other Matters" is largely sympathetic to the approach taken by Koh \& Buchwald. ${ }^{14}$ He expresses a concern that ICC jurisdiction over aggression will upset the minimum degree of world public order that has been achieved to date and that arrogating responsibility of matters with respect to peace and security to the ICC is inconsistent with a proper balance between judicial and political power.

Tom Dannenbaum also shares the concern that the aggression amendments agreed upon in Kampala might be interpreted so as to cover, unjustifiably in his view, humanitarian intervention. ${ }^{15}$ However, he argues that prosecutions of nationals of states who have not accepted the aggression amendments (particularly what Koh \& Buchwald term "proxy prosecutions") would not be contrary to international law and that the nature of aggression is not unique so as to make its prosecution different from the other crimes included in the Rome Statute. He also engages with one of the points made by Alain Pellet in his response to Koh, namely that the drafters of the aggression amendments ought to have included attacks by nonstate actors in the scope of the crime, arguing that to have done so would have missed the point of criminalizing aggression.

In his piece, "The Kampala Amendment on the Crime of Aggression post-2017”, Andreas Zimmermann tries to look forwards rather than backwards. ${ }^{16} \mathrm{He}$ concerns himself with the options available for those actors that will be concerned with activating the Court's jurisdiction in 2017 (as well the challenges posed by that

${ }^{10}$ For a discussion of these issues, see Stefan Barriga, Exercise of Jurisdiction and Entry Into Force of the Amendments on the Crime of Aggression, Belgian Interministerial Commission for Humanitarian law: COlloquium “From Rome to Kampala” (2012).

${ }^{11}$ Dapo Akande, Prosecuting Aggression: The Consent Problem and the Role of the Security Council, WORKING PAPER, OXFORD INSTITUTE FOR ETHICS, LAW AND ARMED CONFLICT (2010).

12 Harold Hongju Koh \& Todd F. Buchwald, The Crime of Aggression: The United States Perspective, 109 AJIL 257, 292 (2015).

13 See Alain Pellet, Response to Kob and Bucbwald's Article: Don Quixote and Sancho Panza Tilt at Windmills, 109 AJIL 557, 562-563 (2015) \& Bing Bing Jia, The Crime of Aggression as Custom and the Mechanisms for Determining an Act of Aggression, 109 AJIL 569 (2015).

${ }^{14}$ Nicholas Rostow, The International Criminal Court, Aggression, and Other Matters: A Response to Koh and Buchwald, 109 AJIL UNBOUND 230 (2015).

15 Tom Dannenbaum, Politics, the Rule of Law, and the Role of the Crime of Aggression, A Response to Koh and Buchwald, 109 AJIL UNBOUnD 235 (2015).

16 Andreas Zimmermann, Alea iacta est: The Kampala Amendment on the Crime of Aggression post-2017: A Response to Koh and Buchwald, 109 AJIL UnBOUND 240 (2015). 
process). In particular, he addresses the challenges that will be faced by the Assembly of States Parties in making the activation decision after 1 January 2017; the United Nations Security Council in referring situations involving aggression to the Court; and individual states.

Looking still further ahead, Sarah Williams considers one particular challenge that is likely to arise if (or perhaps when) the ICC actually engages in prosecution for aggression. ${ }^{17}$ The Court will of course only prosecute individuals but given that the crime of aggression, unlike other crimes within the court's jurisdiction, requires a link to state conduct, the interests of states will loom large in such prosecution. She argues that the existing legal framework does not include an adequate right of participation for affected states and considers one way of providing a clearer legal basis for states to participate directly in ICC proceedings in respect of the crime of aggression.

${ }^{17}$ Sarah Williams, Aggression, Affected States, and a Right to Participate: A Response to Koh and Buchwald, 109 AJIL UnBOUND 246 (2015). 